\title{
Knowledge and awareness of emergency contraception among women undergoing medical termination of pregnancy in a tertiary care hospital in Andaman and Nicobar Islands
}

\author{
Shreya Barik, Abhishek Malakar*, Ritu Khatuja, Pinky S. K. Sahoo
}

Department of Obstetrics and Gynecology, ANIIMS, Port Blair, Andaman and Nicobar Islands, India

Received: 13 July 2019

Accepted: 30 August 2019

*Correspondence:

Dr. Abhishek Malakar,

E-mail: drabhishekmalakar@gmail.com

Copyright: () the author(s), publisher and licensee Medip Academy. This is an open-access article distributed under the terms of the Creative Commons Attribution Non-Commercial License, which permits unrestricted non-commercial use, distribution, and reproduction in any medium, provided the original work is properly cited.

\begin{abstract}
Background: Emergency contraception (EC) is a safe and cost effective measure, which when used judiciously can avoid unintended pregnancies. This is especially relevant in our country where both population control and unsafe abortions are a serious concern. For any contraceptive to be effective, the general population must have a proper knowledge and a positive attitude towards it. Women who come for medical termination of unwanted pregnancy are the best representatives of this and our study aimed to assess the knowledge and awareness of EC in this group.

Methods: It was a descriptive, cross-sectional study conducted using a predesigned questionnaire among 100 women who came for medical termination of pregnancy at G. B. Pant Hospital, Port Blair. Questions were asked to evaluate their awareness, knowledge and attitude towards EC.

Results: Out of 100 women, only $26 \%$ had heard about EC, mostly from mass media, and seven of these 26 women had correct knowledge of timing of using EC. Four women had used EC before, whereas among others, fear of menstrual irregularity was the major deterrent. A significant association was found between education level and occupation with knowledge of EC.

Conclusions: Although EC is a potent tool to avoid unwanted pregnancies, ignorance and misconceptions regarding EC is unfortunately still prevalent among those who would benefit the most from it. Medical personnel and health workers should be more proactive to propagate benefits of EC and encourage its use, as they are usually the first point of contact to the target population.
\end{abstract}

Keywords: Abortion, Andaman and Nicobar, Awareness, Emergency contraception, Medical Termination of pregnancy

\section{INTRODUCTION}

Population boom has always been a burning problem in our country. Needless to say, this exposes the lack of effective family planning, leading to a growing number of unintended pregnancies. It is estimated that approximately 15.6 million abortions occurred in India in the year 2015 with nearly half of the pregnancies being unintended. ${ }^{1}$ A systematic analysis of worldwide data estimates that approximately $8 \%$ of all maternal deaths are attributable to unsafe abortion and its related complications, which is the same for India also. ${ }^{2,3}$ For those couples resorting to abortions, emergency contraception is a viable option to prevent pregnancy after unprotected sexual exposure.

Emergency contraception (EC) refers to methods of contraception that can be used to prevent pregnancy after 
unprotected sexual intercourse. Most commonly used EC is Levonorgestrel (LNG) which can be taken as a single dose of $1.5 \mathrm{mg}$, or alternatively, taken in 2 doses of 0.75 $\mathrm{mg}$ each, 12 hours apart, within 72 hours of unprotected intercourse. The main mechanism of action of LNG as EC is delaying or inhibiting ovulation. ${ }^{4} \mathrm{LNG}$ in form of EC is available as an 'over the counter' drug in pharmacies as well as free of cost in most government hospitals in India since 2003, by the name 'EC pill'. With LNG, rate of pregnancy is $0.4 \%$ if started within 24 hours and $2.7 \%$ if started within 72 hours which is definitely better than using no contraception at all. ${ }^{5}$

NFHS-4 says only $47.7 \%$ of urban and $33.6 \%$ of rural women had ever heard of EC, whereas mere $0.4 \%$ ever used EC. ${ }^{6}$ This shows the glaring gap between the knowledge, awareness and the practice of EC. This lack of awareness leads to unwanted pregnancies which invariably lead to abortions, whether safe or unsafe, legal or illegal. Education and awareness, as to the very need of emergency contraception, is therefore a practical solution to this problem.

This study aimed to assess the awareness and knowledge regarding emergency contraception among patients visiting the outdoor patient department of our hospital with request for medical termination of pregnancy (MTP) as well as to identify factors contributing to the deficiency of acceptance and usage of EC in reproductive age women in this region.

\section{METHODS}

This was a descriptive, cross-sectional study conducted using a predesigned questionnaire among the women attending the Gynaecology OPD for MTP at G. B. Pant Hospital, Port Blair over a period of 6 months from November 2018 to April 2019. All reproductive age women consenting to participate in the study were included, with exception of fetal and maternal indications for MTP according to MTP Act. ${ }^{7}$ A total of 112 women met our criteria, twelve of them did not wish to participate in the study. So, 100 women were interviewed by the investigator.

The questionnaire included socio demographic parameters like age, residence, education, occupation, marital status, number of children, previous abortions etc. They were asked about their contraceptive practices and type of contraceptive used. Their knowledge regarding emergency contraception was assessed and this opportunity was also used for counseling the women, who did not know about EC. Attitude towards EC was assessed by asking whether they will use it in future and recommend it to other women. A total of 19 questions were asked and answers were duly recorded in excel sheet followed by statistical analysis of the data by SPSS software. Association between awareness of EC and level of education and occupation was tested using Chi-square test for significance of association.

\section{RESULTS}

The demographic characteristics of the study population were analysed and shown in Table 1.

Table 1: Demographic characteristics.

\begin{tabular}{|c|c|c|}
\hline Parameter & Number $(n=100)$ & $\%$ \\
\hline \multicolumn{3}{|l|}{ Age } \\
\hline $18-25$ years & 29 & $29 \%$ \\
\hline 26-30 years & 42 & $42 \%$ \\
\hline $31-35$ years & 24 & $24 \%$ \\
\hline More than 35 years & 05 & $05 \%$ \\
\hline \multicolumn{3}{|l|}{ Residence area } \\
\hline Urban & 57 & $57 \%$ \\
\hline Rural & 43 & $43 \%$ \\
\hline \multicolumn{3}{|l|}{ Religion } \\
\hline Hindu & 82 & $82 \%$ \\
\hline Muslim & 13 & $13 \%$ \\
\hline Christian & 05 & $05 \%$ \\
\hline \multicolumn{3}{|l|}{ Education } \\
\hline Uneducated & 07 & $07 \%$ \\
\hline Primary education & 13 & $13 \%$ \\
\hline Secondary education & 44 & $44 \%$ \\
\hline $\begin{array}{l}\text { Higher secondary } \\
\text { and above }\end{array}$ & 36 & $36 \%$ \\
\hline \multicolumn{3}{|l|}{ Occupation } \\
\hline House wife & 79 & $79 \%$ \\
\hline Student & 02 & $02 \%$ \\
\hline Private worker & 10 & $10 \%$ \\
\hline Government employee & 09 & $09 \%$ \\
\hline \multicolumn{3}{|c|}{ Marital status } \\
\hline Married & 98 & $98 \%$ \\
\hline Unmarried & 02 & $02 \%$ \\
\hline \multicolumn{3}{|l|}{ Age at marriage } \\
\hline Less than 20 years & 56 & $57.14 \%$ \\
\hline $20-25$ years & 35 & $35.71 \%$ \\
\hline More than 25 years & 07 & $07.15 \%$ \\
\hline Total & 98 & $100 \%$ \\
\hline \multicolumn{3}{|l|}{ Number of children } \\
\hline None $(0)$ & 03 & $03 \%$ \\
\hline One (1) & 32 & $32 \%$ \\
\hline Two (2) & 50 & $50 \%$ \\
\hline Three (3) & 09 & $09 \%$ \\
\hline More than three & 06 & $06 \%$ \\
\hline \multicolumn{3}{|c|}{ Age at first pregnancy } \\
\hline$<20$ years & 39 & $40.21 \%$ \\
\hline 20-25 years & 45 & $46.39 \%$ \\
\hline$>25$ years & 13 & $13.4 \%$ \\
\hline Total & 97 & $100 \%$ \\
\hline
\end{tabular}

Majority of our patients (42\%) were between 26-30 years of age. Most of them ( $82 \%)$ were Hindu by religion. About $57 \%$ of the study population came from urban area and $43 \%$ from rural regions. Most patients had secondary education (44\%) while $36 \%$ had higher secondary 
qualification or above. About $79 \%$ of this group were housewives whereas only $19 \%$ were working women. We had two unmarried women and of the ninety eight married women, $50 \%$ had two living children. More than half of women $(57.14 \%)$ were married before 20 years of age.

Table 2: Family planning practices.

\begin{tabular}{|c|c|c|}
\hline Parameter & $\begin{array}{l}\text { Number } \\
(n=100)\end{array}$ & $\%$ \\
\hline \multicolumn{3}{|l|}{ Ever terminated pregnancy? } \\
\hline Once & 08 & $08 \%$ \\
\hline More than once & 05 & $05 \%$ \\
\hline \multicolumn{3}{|l|}{ Ever used contraception? } \\
\hline Yes & 74 & $74 \%$ \\
\hline No & 26 & $26 \%$ \\
\hline \multicolumn{3}{|c|}{ Reason for not using any contraceptive } \\
\hline Lack of knowledge & 15 & $57.69 \%$ \\
\hline Fear of side effect & 07 & $26.92 \%$ \\
\hline Family pressure & 04 & $15.39 \%$ \\
\hline Total & 26 & $100 \%$ \\
\hline \multicolumn{3}{|l|}{ Type of contraceptive used? } \\
\hline Condom & 48 & $64.86 \%$ \\
\hline Oral contraceptive pills (OCP) & 16 & $21.62 \%$ \\
\hline Copper T (CuT) & 09 & $12.16 \%$ \\
\hline DMPA injection & 01 & $01.36 \%$ \\
\hline Total & 74 & $100 \%$ \\
\hline \multicolumn{3}{|c|}{ Decision regarding use of contraception } \\
\hline Self & 08 & $10.81 \%$ \\
\hline Husband & 15 & $20.27 \%$ \\
\hline Family/ In law pressure & 06 & $08.11 \%$ \\
\hline Both & 45 & $60.81 \%$ \\
\hline Total & 74 & $100 \%$ \\
\hline \multicolumn{3}{|l|}{ Began use of contraception } \\
\hline Immediately after marriage & 08 & $10.81 \%$ \\
\hline After one child & 45 & $60.81 \%$ \\
\hline After family is completed & 21 & $28.38 \%$ \\
\hline Total & 74 & $100 \%$ \\
\hline
\end{tabular}

Regarding family planning practices (Table 2), 74\% women had ever used any contraception, and it was found most $(60.81 \%)$ started using contraception only after one child. Among the non-users, lack of knowledge and fear of side effects were most common reasons. There were 13 women who had undergone MTP before, among which five women had done it on more than one occasion. Condom was the most commonly used contraceptive $(64.86 \%)$ followed by oral contraceptive pills $(21.62 \%)$. Decision about contraceptive was taken by both partners in $60.8 \%$ of cases.

Table 3 represents the knowledge and awareness of the study population towards emergency contraceptives. Only $26 \%$ had heard about EC and in them only four women have used EC before. None of the women had any idea of any other method like Copper T acting as EC. Seven of these 26 women had identified the correct timing of effectiveness of EC (within 72 hours of unprotected sexual intercourse). The source of information of EC was mostly mass media like TV, radio, newspaper $(61.54 \%)$ and only two women heard about it from health workers $(7.69 \%)$.

Table 3: Knowledge and attitude towards emergency contraceptives (EC).

\begin{tabular}{|c|c|c|}
\hline Parameter & $\begin{array}{l}\text { Number } \\
(n=100)\end{array}$ & $\%$ \\
\hline \multicolumn{3}{|l|}{ Ever heard about EC? } \\
\hline Yes & 26 & $26 \%$ \\
\hline No & 74 & $74 \%$ \\
\hline Ever used EC? & 04 & $04 \%$ \\
\hline \multicolumn{3}{|c|}{ Among those who have heard of EC $(n=26)$} \\
\hline \multicolumn{3}{|c|}{ Source of Information regarding $E C$} \\
\hline Media (TV/ Radio/ Newspaper) & 16 & $61.54 \%$ \\
\hline Health worker & 02 & $07.69 \%$ \\
\hline Hospital & 08 & $30.77 \%$ \\
\hline \multicolumn{3}{|l|}{ Knowledge about timing of EC } \\
\hline $\begin{array}{l}\text { Within } 72 \text { hours of } \\
\text { unprotected intercourse }\end{array}$ & 07 & $26.92 \%$ \\
\hline Did not know & 19 & \\
\hline Heard about Copper T as EC? & 0 & $0 \%$ \\
\hline \multicolumn{3}{|c|}{ Knowledge of indications of using EC } \\
\hline Failure of barrier methods & 05 & $19.23 \%$ \\
\hline Unprotected sexual intercourse & 11 & $42.31 \%$ \\
\hline Did not know & 10 & $38.46 \%$ \\
\hline \multicolumn{3}{|l|}{ Reason for not using EC this time } \\
\hline $\begin{array}{l}\text { EC may cause menstrual } \\
\text { irregularity }\end{array}$ & 11 & $42.31 \%$ \\
\hline EC may affect future fertility & 04 & $15.38 \%$ \\
\hline $\begin{array}{l}\text { Unawareness regarding } \\
\text { availability }\end{array}$ & 03 & $11.54 \%$ \\
\hline False sense of security & 06 & $23.08 \%$ \\
\hline $\begin{array}{l}\text { Hesitancy to purchase from } \\
\text { pharmacy }\end{array}$ & 02 & $07.69 \%$ \\
\hline \multicolumn{3}{|l|}{ After counselling, how many will } \\
\hline $\begin{array}{l}\text { Use it in future and } \\
\text { recommend it to others? }\end{array}$ & 21 & $80.7 \%$ \\
\hline \multicolumn{3}{|c|}{ Among those who have not heard about EC $(n=74)$} \\
\hline \multicolumn{3}{|c|}{ If had previous knowledge of EC, how many } \\
\hline Would have used it? & 48 & $64.86 \%$ \\
\hline \multicolumn{3}{|l|}{ After counselling, how many will } \\
\hline $\begin{array}{l}\text { Use it in future and recommend } \\
\text { to others? }\end{array}$ & 57 & $77 \%$ \\
\hline \multicolumn{3}{|c|}{ What could have helped to increase awareness? } \\
\hline Counselling by health workers & 15 & $20.27 \%$ \\
\hline Advertisement and hoardings & 10 & $13.51 \%$ \\
\hline Health camps & 03 & $04.05 \%$ \\
\hline All of the above & 46 & $62.17 \%$ \\
\hline
\end{tabular}

Among the 26 women who have heard about EC, the most common reason for not using was fear of menstrual irregularity $(42.31 \%)$ followed by a false sense of security $(23.08 \%)$. There were 11 women $(42.31 \%)$ who 
knew unprotected sexual intercourse as an indication of EC, and nearly similar percentage of women did not know when to use it $(38.46 \%)$. For attitude regarding future use and recommendation, 21 out of 26 women who were presently aware of EC were willing to use it and recommend to others. We found 48 out of the 74 women who have not heard about EC, would have used it if they had prior knowledge, i.e. approximately $65 \%$ of these women would have used EC and could have avoided MTP this time. These 74 women had the opinion that counselling by health workers, advertisements, hoardings and health camps can help increase awareness about EC among the general population.

Table 4: Association between level of education and awareness about EC.

\begin{tabular}{|c|c|c|c|c|}
\hline \multirow{2}{*}{ Education } & \multirow{2}{*}{ Frequency (Percentage) } & \multicolumn{2}{|c|}{ Heard about EC } & \multirow{2}{*}{ Total } \\
\hline & & Yes & No & \\
\hline \multirow{3}{*}{ Uneducated } & Count & 0 & 7 & 7 \\
\hline & $\%$ within education & $0.0 \%$ & $100.0 \%$ & $100.0 \%$ \\
\hline & \% within EC & $0.0 \%$ & $9.5 \%$ & $7.0 \%$ \\
\hline \multirow{3}{*}{ Primary } & Count & 0 & 13 & 13 \\
\hline & $\%$ within education & $0.0 \%$ & $100.0 \%$ & $100.0 \%$ \\
\hline & $\%$ within EC & $0.0 \%$ & $17.6 \%$ & $13.0 \%$ \\
\hline \multirow{3}{*}{ Secondary } & Count & 8 & 36 & 44 \\
\hline & $\%$ within education & $18.2 \%$ & $81.8 \%$ & $100.0 \%$ \\
\hline & $\%$ within EC & $30.8 \%$ & $48.6 \%$ & $44.0 \%$ \\
\hline \multirow{3}{*}{$\begin{array}{l}\text { Higher secondary } \\
\text { and above }\end{array}$} & Count & 18 & 18 & 36 \\
\hline & $\%$ within education & $50.0 \%$ & $50.0 \%$ & $100.0 \%$ \\
\hline & $\%$ within EC & $69.2 \%$ & $24.3 \%$ & $36.0 \%$ \\
\hline \multirow{3}{*}{ Total } & Count & 26 & 74 & 100 \\
\hline & $\%$ within education & $26.0 \%$ & $74.0 \%$ & $100.0 \%$ \\
\hline & \% within EC & $100.0 \%$ & $100.0 \%$ & $100.0 \%$ \\
\hline
\end{tabular}

Chi-square $=19.202, \mathrm{df}=3, \mathrm{p}<0.01$, Significant at $1 \%$ level of significance

Table 5: Association between occupation and awareness about EC.

\begin{tabular}{|lllll|}
\hline \multirow{2}{*}{ Occupation } & Frequency (Percentage) & Heard about EC & No & Total \\
\hline \multirow{3}{*}{ Housewife } & Count & 15 & 64 & 79 \\
\cline { 2 - 5 } & \% within occupation & $19.0 \%$ & $81.0 \%$ & $100.0 \%$ \\
\cline { 2 - 5 } & \% within EC & $57.7 \%$ & $86.5 \%$ & $79.0 \%$ \\
\hline \multirow{3}{*}{ Student } & Count & 1 & 1 & 2 \\
\cline { 2 - 5 } & \% within occupation & $50.0 \%$ & $50.0 \%$ & $100.0 \%$ \\
\cline { 2 - 5 } Working women & \% within EC & $3.8 \%$ & $1.4 \%$ & $2.0 \%$ \\
\cline { 2 - 5 } & Count & 10 & 9 & 19 \\
\cline { 2 - 5 } & \% within occupation & $52.6 \%$ & $47.4 \%$ & $100.0 \%$ \\
\hline \multirow{3}{*}{ Total } & Count & $38.5 \%$ & $12.2 \%$ & $19.0 \%$ \\
\cline { 2 - 5 } & \% within occupation & 26 & 74 & 100 \\
\hline & \% within EC & $26.0 \%$ & $74.0 \%$ & $100.0 \%$ \\
\hline
\end{tabular}

Chi-square $=9.622, \mathrm{df}=2, \mathrm{p}<0.01$, Significant at $1 \%$ level of significance

There was significant association between level of education and awareness (Chi-square $=19.202, \mathrm{p}<0.01$ ) as well as between occupation and awareness (Chi-square $=9.622, \mathrm{p}<0.01)($ Table 4 and 5).

\section{DISCUSSION}

For any contraception to be effective, the general population should have proper knowledge and a positive attitude towards it. Women who come with unwanted pregnancy for MTP are one of the best representatives for assessment of this knowledge. Our study targeted this population for the evaluation of knowledge and awareness of emergency contraception.

Demographically, our study population consisted mostly of the reproductive age group. A total of $74 \%$ of our study population had used some form of contraception till 
now which was more than some contemporary studies by Mehra et al $(66 \%)$ and Preeti et al $(50 \%)$ but lower than the study by Takkar $\mathrm{N}$ et al $(81.1 \%) .{ }^{5,8,9}$ This is probably because the latter study was done among the more educated working women whereas most women in our study were housewives. The most common method of contraception used was condom $(64.86 \%)$, similar to the study by Mehra et al $(75 \%)$ and far more than Preeti et al $(34 \%){ }^{5,8}$ High failure rate of condom was the probable cause of these unwanted pregnancies. Twenty six percentage did not ever use any contraception contrary to $49.34 \%$ found in a study from Gujarat, a comparatively optimistic finding. ${ }^{5}$ Lack of knowledge was the main reason as also found by Prachi et al, which only strengthens the well-known fact, lack of education. ${ }^{10}$ Both partners actively participated in deciding mode of contraception in most of our cases $(60 \%)$ which was a very positive finding whereas in a study by Preeti et al, mainly husbands took the decision $(40.79 \%){ }^{5}$

EC is vital and comparatively newer concept which can potentially reduce the incidence of unwanted pregnancies. There have been different study groups among patients, undergraduate students and gynaecologists regarding awareness of EC. Studies among college students in India show the awareness regarding EC as $86-100 \%$ which is quite satisfactory. ${ }^{11-14}$ On the contrary, Tripathi R et al, showed that knowledge about EC among doctors is surprisingly inadequate. ${ }^{15}$ This corresponds to the results of another study showing a strong misconception regarding EC even among gynaecologists so much so that only $26 \%$ had ever prescribed EC. ${ }^{16}$

The reluctance to promote or prescribe EC on part of the gynaecologist reflects the lack of awareness among the patients and hence the general population. The studies from all over India show the awareness of EC in general population ranges from $14-22 \%$ whereas in a multicountry analysis, overall awareness and practice of EC in India was found to be $10.7 \%$ and $0.2 \%$ respectively. ${ }^{10,17-19}$ There have been two studies like ours where awareness regarding $\mathrm{EC}$ was assessed in women who came for MTP, by Mehra $\mathrm{R}$ et al and Yadav $\mathrm{P}$ et al showing the awareness of EC in these groups to be as diverse as $1 \%$ and $23.68 \% .^{5,8}$ Awareness in the former study was so low may be due to the fact that it was done in 2004, soon after introduction of EC in India.

We conducted the study in Andaman and Nicobar Islands, which is separated from the main land by about 1200 kilometres which makes this island quite isolated from main stream. In our study $26 \%$ of women were aware about EC and only $60 \%$ of those had correct knowledge about indications of use and 4 out of 100 women had used EC in past. Seven women had perfect knowledge about timing but none of them had any idea about any other method being used as EC, similar to a study from Delhi. ${ }^{8}$ Half of the women with higher secondary education or above, were aware of EC.
Working women had a better level of awareness (more than $50 \%$ ), which is similar to the study by Prateek et al showing awareness of $65 \% .{ }^{20}$ Although the working women are more aware of EC, the awareness doesn't reflect in its practice, as we found $21 \%$ of working women using EC, but it still remains better than other studies among working women with practice being only $1.1 \%$ and $8.2 \% .^{9,20}$ Regarding source of knowledge, all studies point to the mass media being the most common source, our study being no exception. This shows unfortunately, there is lesser encouragement and information from health care providers.

In our study we found that among those who did not know about EC, approximately $65 \%$ would have used EC if they had prior knowledge, and after counseling, $77 \%$ agreed to use it in future and recommend to others. Another study showed willingness of $83 \%$ in study population. ${ }^{17}$ These results from various contemporary studies show that once the target population is properly counselled regarding EC and its benefits and the misconceptions cleared, they are more receptive to the idea of using emergency contraceptives. Hence counselling by health workers and medical personnel, advertisements and outreach health camps may have an immense role to play. An analysis by Palermo $\mathrm{T}$ et al showed the awareness and practice of EC was very low all over the world. $^{21}$ Developed countries like United States and Australia also face the same problem of underutilisation of EC. . $^{22,23}$

The limitation of our study is that it is with a small sample size and a single centric trial.

\section{CONCLUSION}

Although the use of regular contraceptives are the backbone of effective family planning and spacing, emergency contraceptives are a potent but highly underutilised tool, which, with perfect knowledge and use, can potentially reduce many unwanted pregnancies and abortions, which continue to remain an important cause of maternal morbidity and mortality as well as a burden on health care resources. The main hindrance is inadequate or irrational knowledge, or sometimes complete ignorance to the concept of contraception itself. Doctors and other health care professionals should take more initiative as they play a pivotal role in counselling patients at their first contact than what mass media can achieve.

\section{Funding: No funding sources \\ Conflict of interest: None declared \\ Ethical approval: The study was approved by the Institutional Ethics Committee}

\section{REFERENCES}

1. Singh S, Shekhar C, Acharya R, Moore AM, Stillman M, Pradhan MR, et al. The incidence of 
abortion and unintended pregnancy in India, 2015. Lancet Glob Health. 2018;6:e111-20.

2. Say L, Chou D, Gemmill A, Tunçalp Ö, Moller AB, Daniels J, et al. Global causes of maternal death: a WHO systematic analysis. Lancet Glob Health. 2014;2:e323-33.

3. Registrar General, India, 2006. Maternal mortality in India, 1997-2003: Trends, Causes and Risk Factors (Sample Registration System). Esocialsciences.com, Working Papers.

4. World Health Organization. Fact Sheet: Emergency contraception. Available at: https://www.who.int/news-room/fact-sheets/detail /emergency-contraception.

5. Yadav P, Sinha A, Jaykaran, Mody P, Panwar AS, Kantharia ND. Awareness about emergency contraceptives pill in women who came for medical termination of pregnancy. National J Physiol Pharma Pharmacol. 2011;1(2):68-78.

6. Ram F, Singh PB, Kant S, Lhungdim, Hemkhothang S, Singh C, et al. National Family Health Survey-4 (2015-16). Economic and political weekly. LII.; 2017:66-70.

7. Ministry of Health and Family Welfare. Fact Sheet: The Medical Termination of Pregnancy Act, 1971. Available at: https://mohfw.gov.in/acts-rules-andstandards-health-sector/acts/mtp-act-1971.

8. Reeti M, Poonam G, Deepti D, Anju H. Knowledge of emergency contraception among women coming for induced abortion. J Ostet Gynecol India. 2006;56(3):233-5.

9. Takkar N, Goel P, Saha PK, Dua D. Contraceptive practices and awareness of emergency contraception in educated working women. Indian J Med Sci. 2005;59(4):143-9.

10. Renjhen P, Kumar V, Rathi A, Loukya A. Contraceptive practices and awareness about emergency contraception among women attending a tertiary care hospital of Delhi, India. Int J Reprod Contracept Obstet Gynecol. 2019;8(3):1047-54.

11. Agrawal VK, Agrawal P. Knowledge, awareness and perception of female students of Emergency contraceptive pills. J Behav Health. 2013;2(3):230-5.

12. Shelat PR, Hiroriya NH, Kumbar S. Knowledge and attitude towards the use of emergency contraceptive pills among college students. Int $\mathbf{J}$ Basic Clin Pharmacol. 2012;1(2):77-84.

13. Relwani N, Saoji A, Kasturwar NB, Nayse J. Emergency contraception: exploring the knowledge, attitude and practices of engineering college girls in nagpur district of Central India. Nat J Com Med. 2012;3(1):14-9.

14. Chandna A, Nath J, Dhingra D. Awareness of emergency contraception among $1^{\text {st }}$ year medical students. Int J Cont Med Res. 2016;3(6):1568-70.

15. Tripathi R, Rathore AM, Sachdev J. Emergency contraception: knowledge, attitude and practice among health care providers in North India. J Obstet Gynecol Res. 2003;29:142-6.

16. Sunil Kumar KS et al. Emergency contraception, a study on knowledge, attitude and practice among gynecologists. Int J Reprod Contracept Obstet Gynecol. 2016;5(1):198-201.

17. Kaushal M, Maru L, Dave A. Emergency contraceptive knowledge, attitudes and practices in women presenting to family planning outpatient clinic in central India. J South Asian Fed Obstet Gynaecol. 2014;6(1):21-4.

18. South India: Biradar SM. A survey of knowledge and perceptions towards emergency contraceptives among working women of Bijapur, South India. Int J Pharm Bio Sci. 2013;4(1):583-7.

19. Westley E, Palermo T, Bleck J. Knowledge and use of emergency contraception: a multicountry analysis. Int Perspect Sexual Repro Health. 2014;40(2):79-93.

20. Harne P, Khan AM. Awareness and usage of emergency contraceptive pills among working women: a hospital based survey from north India. Int J Reprod Contracept Obstet Gynecol. 2016;5(4):1202-6.

21. Palermo T, Bleck J, Westley E. Knowledge and use of emergency contraception: a multicountry analysis. Int Perspect Sexual Repro Health. 2014;40(2):79-93.

22. Devine KS. The underutilization of emergency contraception. Am J Nurs. 2012;112(4):44-50.

23. Mazza D, Harrison CM, Taft AJ, Britt HC, Hobbs M, Stewart K, et al. Emergency contraception in Australia: the desired source of information versus the actual source of information. Med J Aust. 2014;200(7):414-5.

Cite this article as: Barik S, Malakar A, Khatuja R, Sahoo PSK. Knowledge and awareness of emergency contraception among women undergoing medical termination of pregnancy in a tertiary care hospital in Andaman and Nicobar Islands. Int J Reprod Contracept Obstet Gynecol 2019;8:3970-5. 